\title{
АКТУАЛЬНІ ПРОБЛЕМИ ФОРМУВАННЯ ОДОРАТИВНОЇ ЛЕКСИКИ В УКРАЇНСЬКІЙ МОВІ
} мові.

Іншакова I. С. Актуальні проблеми формування одоративної лексики в українській

Лексика сприйняття постійно перебуває в колі уваги науковців. У статті обгрунтовується необхідність комплексного діахронічного розгляду на широкому історичному матеріалі формування одоративної лексики як окремої семантичної групи в українській мові через відсутність спеціальних праць із розглядуваної проблеми.

Ключові слова: лексика відчуття, семантична група, запах, одоративна лексика.

Иншакова И. Е. Актуальные проблемы формирования одоративной лексики в украинском языке.

Лексика восприятия постоянно пребывает в центре внимания ученых. В статье обосновывается необходимость комплексного диахронического рассмотрения на широком историческом материале формирования одоративной лексики как отдельной семантической группы в украинском языке из-за отсутствия специальных работ по изучаемой проблеме.

Ключевые слова: лексика восприятия, семантическая группа, запах, одоративная лексика.

Inshakova I. Y. Contemporary problems of formation of odorative vocabulary in the Ukrainian language.

Vocabulary of perception is constantly attracting researchers' attention. The article deals with the necessity of complex diachronic examination based upon road historical material of formation of odorative vocabulary as a separate semantic group in the Ukrainian language. Works on the given problem have not been represented yet.

Key words: vocabulary of perception, semantic group, odour, odorative vocabulary.

Вивчення окремих семантичних груп словникового складу мови $\epsilon$ традиційним в українському мовознавстві. Ідея системності лексики отримала загальне визнання та знайшла своє втілення в дослідженнях українських лексикологів. Досі досліджувалася історія певних семантичних груп лексики: назв одягу (Г. М. Миронова), назв хвороб (Т. В. Олещук), назв страв і продуктів харчування (В. I. Невойт), ботанічної номенклатури (I. В. Сабадош), географічної номенклатури (П. П. Чучка), назв грошей і грошових одиниць (Є. І. Чернов) та ін.

Мета нашої статті - актуалізувати необхідність розгляду формування одоративної лексики в українській мові.

Серйозні дослідження в галузі історичної лексикологї знайшли відображення в дисертаціях, авторефератах, лексикологічних збірниках, у досягненнях східнослов'янської лексикографії, науковій періодиці, виданнях українських пам'яток.

Історію окремих макро- та мікросистем подає колективна монографія „Історія української мови. Лексика і фразеології (Київ, 1982). 
Повне ж дослідження історії лексичного складу української мови неможливе без з'ясування історії окремих семантичних груп.

Мова певним чином відображає процес пізнання людиною дійсності. I початковим етапом цього процесу $є$ сприйняття. Лексика сприйняття постійно перебуває в колі уваги вітчизняних лінгвістів. Проте до сьогодні, на жаль, не було спроб комплексного опису історії одоративної лексики української мови.

Підвищений інтерес у суспільстві до феномену запаху останні кілька десятиліть викликає увагу у вітчизняній i зарубіжній лінгвістиці до відповідної лексики.

Запах досліджується в різних аспектах ольфакторної семантики: фізіології, соціології, культурології, психології. Відомі окремі праці, присвячені частковим аспектам опису цієї лексики в українській, російській лінгвістиці, психолінгвістиці (І. Я. Франко, О. І. Білецький, В. В. Виноградов, В. П. Сидельников, Л. Вайсгербер, В. Дорошевський, Л. М. Васильєв, Ю. Н. Караулов, А. П. Василевич, Е. В. Гейко, Л. Б. Крюкова, В. В. Лещенко, Н. С. Павлова, І. Г. Рузін, Р. М. Фрумкіна, А. Вежбицька, А. В. Житков, Н. А. Ніколіна та ін.).

Дослідники підкреслюють надзвичайну обмеженість мовних засобів, що використовуються людиною при описі запахів. Немає класифікацій одоративної лексики, подібних до класифікацій кольорів .

Проте засоби передачі запаху різноманітні, активно використовуються дієслова, іменники, прикметники в переносному значенні, синкретичні образи запаху. Кожна частина мови утворює свій семантичний ряд, наприклад:

- іменники - дух, духмяність, чад, аромат, сморід, запах, пахощі;

- дієслова - пахтіти, смердіти, тхнути, ароматизувати, чадіти, духмяніти, п'янити;

- прикметники - пахучий, духовитий, ароматний, чадний, тухлий, запашний, благоуханний, медовий, медвяний, полиновий, м'ятний, чебречевий;

- прислівники - ароматно, пахуче, чадно, духмяно, п'янко, запашно, курно, димно.

Деякі слова служать засобом передачі запаху лише в певному контексті.

Науковці, аналізуючи семантику синтаксичних конструкцій зі значенням запаху, звертають увагу на явища синкретизму, бо часто перетинаються компоненти смакових, дотикових, зорових відчуттів та ін.

Одоративна лексика відображає специфічне сприйняття світу, служить для повної характеристики пейзажу, персонажа, предмета, явища.

Детальний розгляд ольфакторної лексики покликаний допомогти встановити історію окремих слів, системні відношення (синонімії, антонімії, узагальнення, диференціації та ін.), зміни в семантиці лексем, розвиток вторинних значень у процесі становлення, функціонування тощо. 
Лексеми на позначення запаху часто розглядаються в трьох аспектах: походження, значення, уживання. Також розглядатимемо індивідуальне вживання, ситуативне значення розглядуваних слів у відповідних контекстах.

На нашу думку, у роботі необхідно розв'язати низку завдань:

1) виявити склад лексики із семою “запах" на різних етапах писемної історії української мови;

2) проаналізувати становлення семантики ольфакторної лексики;

3) здійснити детальний опис функціонування досліджуваної семантичної групи;

4) установити рівень продуктивності розгляданих лексем на різних етапах розвитку мови;

5) уточнити етимологію, хронологію окремих одоративів;

6) визначити специфіку української ольфакторної картини світу.

Предмет вивчення - одоративна лексика української мови. Це слова різних граматичних категорій, що містять значення запаху (іменники, дієслова, прикметники, прислівники).

Об'єктом дослідження стане специфічна лексико-семантична група слів на позначення запаху в історії української мови.

Для виконання завдань буде залучено широкий фактичний матеріал: різноманітні за жанрами й стилями загальновідомі оригінальні й перекладні пам'ятки XI-XIII ст. (літописи, житія, хроніки та ін.), тексти середньоукраїнської мови XIV-XVIII ст. (лексикони, граматики, порадники, розмовники) та історичні словники, що відображають лексику зазначеного періоду функціонування української мови.

До фактичного матеріалу віднесемо залучимо не лише нейтральні, а й стилістично марковані (розмовні, просторічні, діалектні) одиниці, що дозволить максимально повно дослідити лексичну групу з семантикою запаху.

Факти для характеристики праслов'янського періоду будуть узяті 3 різних етимологічних словників слов'янських мов, авторських розвідок, присвячених праслов'янському етапу.

Такий фактичний матеріал послужить фоном, перспективою, без яких неможливо зрозуміти всю історію ольфакторної лексики в українській мові, а також сприятиме висвітленню історії досліджуваної семантичної групи в усій складності, багатогранності та дозволить охарактеризувати іiі місце, роль у лексичній системі.

Вибір методів дослідження зумовлений специфікою об'єкта та завданнями роботи. Основними стануть порівняльно-історичний, описовий методи, прийоми лінгвостатистики. Крім загальнонаукових методів аналізу й синтезу, використаємо метод системного опису лексики, часткові методи й методики: суцільної вибірки лексичного матеріалу, лінгвістичного опису з елементами компонентного аналізу та ін. 
Роль засобів передачі відчуття запаху значно помітна у творах українських письменників XIX століття Панаса Мирного, I. Нечуя-Левицького, М. Коцюбинського, у поезії Т. Шевченка, Лесі Українки та ін. Запахові образи в російській літературі пов'язані зі становленням «натуральної школи» 40-50-х років ХІХ ст.: С. Тургенєв, Л. Толстой, А. Фет.

Художньо-стильовій ролі слів лексико-семантичного поля “запах" у творах I. Буніна присвячена кандидатська дисертація М. В. Одинцової (2008), функціонування лексики з семою “запах" у мові, мовленні і тексті розглядається в кандидатській дисертації Н. С. Павлової (2006), мовні засоби вираження одоративної лексики аналізували І. Я. Франко, О. І. Білецький, А. П. Василевич, Е. В. Гейко, Л. Б. Крюкова, В. В. Лещенко, В. В. Дятчук, Л. Ставицька, І. Г. Рузін, Р. М. Фрумкіна, А. Вежбицька та багато інших мовознавців. Це пов'язано 3 грунтовними дослідженнями лексичних систем, семантичних полів.

Опубліковані окремі статті, монографії, дисертації 3 історії одоративної лексики допоможуть нам уточнити об'єкт дослідження, визначити хронологічні межі роботи.

Наукова новизна такого дослідження полягатиме в тому, що вперше в україністиці буде проведено на широкому історичному матеріалі проведемо комплексний діахронічний розгляд семантичної групи одоративів.

До наукового обігу введемо в повному обсязі мовний матеріал у розглядуваному аспекті, оброблений за етимологічними, тлумачними, словотвірними словниками, іншими інформаційними джерелами.

Основні положення роботи, одержані результати дадуть змогу розширити, поглибити сучасні уявлення про формування, еволюцію одоративів, становитимуть певну цінність для окремих питань історичної лексикології.

Матеріали дослідження можуть бути використані при підготовці фундаментальних узагальнюючих праць з історії лексикології, створенні підручників, посібників, у лексикографічній практиці, у вузівській, шкільній лінгводидактиці, укладанні відповідного спецкурсу. Ними можуть скористатися студенти при підготовці курсових, кваліфікаційних, магістерських робіт.

Отже, актуальність нашого майбутнього доробку зумовлена необхідністю комплексного опису історії одоративної лексики української мови та відсутністю спеціальних праць із розглядуваної проблеми.

\section{Література}

1. Дятчук В. В. Як передається в мові відчуття запаху / В. В. Дятчук // Культура слова. - К., 1978. - Вип. 15. - С. 35- 42.

2. Павлова Н. С. Лексика с семой «запах» в языке, речи и тексте: автореф. дис. на соискание учен. степени канд. филол. наук: 10.02.01 «Русский язык» / Наталия Сергеевна Павлова. - Екатеринбург, 2006. - 19 с.

3. Ставицька Л. Стать крізь призму запаху / Л. Ставицька // Вісник Львівського ун-ту. Серія філологічна. - 2006. - Вип. 38. - Ч. ІІ. - С. 72-78.

Стаття надійшла до редакиї 19.10.2010 p. 